Bull. Chem. Soc. Ethiop. 2019, 33(3), 467-474.

ISSN 1011-3924

(c) 2019 Chemical Society of Ethiopia and The Authors

Printed in Ethiopia

DOI: https://dx.doi.org/10.4314/bcse.v33i3.7.

\title{
SYNTHESIS, X-RAY ANALYSIS AND ANTIBACTERIAL STUDY OF SILVER COMPLEX WITH ETHYL-5-HYDROXY-2-OXO-2H-CHROMENE-3-CARBOXYLATE
}

\author{
Hajira Rehman ${ }^{1 *}$, Zulfiqar Ali ${ }^{2}$, Tanzeela Gulab Shahzady ${ }^{1}$, M. Amin Abid ${ }^{3}$, Shahid Nazir ${ }^{4}$, \\ Habib Hussain ${ }^{3}$, Asmat Zahra ${ }^{5}$ and Imdad Hussain ${ }^{6}$ \\ ${ }^{1}$ Department of Chemistry, Lahore Garrison University, DHA, Lahore, Pakistan \\ ${ }^{2}$ Department of Basic Sciences \& Humanities, University of Engineering \& Technology, \\ Lahore, KSK Campus, Pakistan \\ ${ }^{3}$ Department of Biomedical Engineering Basic Sciences, University of Engineering \& \\ Technology, Lahore, Narowal Campus, Pakistan \\ ${ }^{4}$ Department of Chemistry, COMSATS University, Islamabad, Lahore Campus, 54000 Lahore \\ Pakistan \\ ${ }^{5}$ Institute of Chemistry, University of the Punjab, Lahore, Pakistan \\ ${ }^{6}$ Department of Chemistry, University of Engineering \& Technology, Lahore, Pakistan
}

Received September 14, 2018; Revised August 15, 2019; Accepted August 282019

\begin{abstract}
A novel silver complex $\left[\mathrm{Ag}\left(\mathrm{C}_{12} \mathrm{H}_{9} \mathrm{O}_{5}\right)_{2}\right]$ was synthesized by the reaction of silver salt $\left(\mathrm{AgNO}_{3}\right)$ and coumarin based ligand (ethyl-5-hydroxy-2-oxo- $2 \mathrm{H}$-Chromene-3-carboxylate) at room temperature. The synthesized complex was characterized by using different analytical techniques like melting point (mp), infrared (IR) spectroscopy, powder X-ray diffraction (PXRD), thermo gravimetric analysis (TGA), atomic absorption spectroscopy (AAS) and mass spectrometry (ESI-MS). Ligand showed activity with MIC $20 \mu \mathrm{g} / \mathrm{mL}, 15 \mu \mathrm{g} / \mathrm{mL}$, $15 \mu \mathrm{g} / \mathrm{mL}$ for $S$. aurues, E. coli and S. typhi, respectively whereas MIC values of Ag-complex for above mentioned bacterial strains were found to be $15 \mu \mathrm{g} / \mathrm{mL}, 10 \mu \mathrm{g} / \mathrm{mL}, 10 \mu \mathrm{g} / \mathrm{mL}$, respectively. Ligand could not inhibit the growth of $B$. Subtilis, $P$. auruginosa, MRSA but Ag-complex showed MIC $30 \mu \mathrm{g} / \mathrm{mL}, 25 \mu \mathrm{g} / \mathrm{mL}$ for $B$. Subtilis and $P$. auruginosa. It also remained ineffective against MRSA.
\end{abstract}

KEY WORDS: Silver complex, Ethyl-5-hydroxy-2-oxo-2H-Chromene-3-carboxylate, Antibacterial study

\section{INTRODUCTION}

Coumarin and its derivatives form an important class of benzopyrones and found in nature. Many complex natural compounds contain them as structural subunits and have various numerous biological activities, such as antitumor [1], anti-HIV (NNRTI) [2], antioxidation [3], antimicrobial activity [4] and anticancer activity [5]. The extensive biological activities of coumarin derivatives have gained their prominent position in the area of synthetic chemistry and pharmacology.

Transition metals like silver have been used for years as anti-microbial agents because it has low toxicity than other transition metals. A silver compound which is frequently used is silver(I) sulfazine; it is used in the treatment of severe burns to prevent from bacterial infections [6]. Chlorhexidine, silver sulfadiazine is an anti-infective metal complex against catheter infections in vivo [7]. It is well established that only silver in its ionic or complexed forms is antimicrobially active, while the elemental silver, even in the so-called "nanocrystalline" state, is not [8]. Silver-containing compounds are attractive because of the fact that in the range of the applicable concentrations, silver ions do not exhibit toxicity and carcinogenic activities [9]. There is an increased interest in the potential use of silver(I) as a therapeutic agent for different antimicrobial applications.

*Corresponding author. aries_cute8@hotmail.com

This work is licensed under the Creative Commons Attribution 4.0 International License 
By keeping in view the above intriguing applications, it's highly attractive and fascinating to synthesize different type of $\operatorname{Ag}(\mathrm{I})$ complexes with biomedicinally active ligands. In this paper, the synthesis, characterization, and antibacterial properties of $\mathrm{Ag}(\mathrm{I})$ complex with ethyl-5hydroxy-2-oxo- $2 \mathrm{H}$-chromene-3-carboxylate ligand are being reported.

\section{EXPERIMENTAL}

Synthesis of ethyl-5-hydroxy-2-oxo-2H-chromene-3-carboxylate

According to the procedure followed by Teizo Sugino et al. [10] a mixture of salicylaldehyde $(1.22 \mathrm{~g}, 10.0 \mathrm{mmol})$, diethyl malonate $(1.60 \mathrm{~g}, 10.0 \mathrm{mmol})$ and a few drops of piperidine was mixed and ground well for $5 \mathrm{~min}$ at room temperature. The reaction mixture was neutralized with dil. $\mathrm{HCl}$ and then the crystalline product was isolated by filtration to give 3ethoxycarbonylcoumarin $(2.07 \mathrm{~g}$ ) in $95 \%$ yield (Figure 1$)$. The crude crystals thus obtained were recrystallized from EtOH to give white crystalline solid. The proposed structure of silver complex with ethyl-5-hydroxy-2-oxo-2H-chromene-3-carboxylate is given in Figure 2.

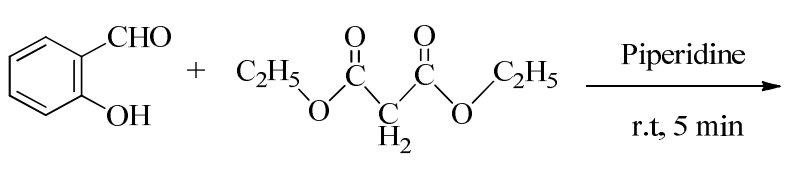<smiles>CCOC(=O)c1cc2c(O)cccc2oc1=O</smiles>

Figure 1. Synthesis of ethyl-5-hydroxy-2-oxo-2H-chromene-3-carboxylate.<smiles></smiles>

Proposed structure I

Figure 2. Proposed tentative structure of silver complex with ethyl-5-hydroxy-2-oxo-2Hchromene-3-carboxylate.

\section{Equipment}

Melting point was determined using Scientific Electrothermal melting point apparatus (1401Q). The vibrational studies of the complex were performed on Nicolet 6700P Infrared Spectrometer (USA). The structural parameters were calculated using PAN analytical (X'Pert PRO) diffractometer (using $\mathrm{Cu}-\mathrm{K} \alpha$ radiation). Thermal measurements were performed on TGA/DSC (Q600) purging nitrogen gas using alumina crucible. Mass spectrum of complex was obtained on Mass spectrometer (1200 series, Agilent technology, with scanning speed up to $5250 \mu / \mathrm{s}$, 
quadrupole, mass range $\mathrm{m} / \mathrm{z}=2-3000$ ) while AAS experiments were performed on Atomic Absorption Spectrometer (Varian AA240).

\section{RESULTS AND DISCUSSION}

\section{Melting point}

Melting point of the complex was determined by using melting point apparatus. The silver complex showed melting point in a range of $168-175{ }^{\circ} \mathrm{C}$ which was not comparable with that of reactants, i.e. $\mathrm{AgNO}_{3}\left(212{ }^{\circ} \mathrm{C}\right)$ and ethyl-5-hydroxy-2-oxo- $2 \mathrm{H}$-Chromene-3-carboxylate $\left(94{ }^{\circ} \mathrm{C}\right)$ which indicated the completion of the reaction and establishment of new phase as a result of a chemical reaction.

\section{Infrared studies}

IR study of synthesized complex verified the presence of ethyl-5-hydroxy-2-oxo- $2 \mathrm{H}$-chromene3 -carboxylate. The stretching vibration of $\mathrm{C}-\mathrm{H}$ corresponding to alkene was recorded at 3010 $\mathrm{cm}^{-1}$ while a peak due to symmetric stretch of C-H of alkane was observed at $2888 \mathrm{~cm}^{-1}$ [12]. Two strong bands of alkane $\mathrm{C}-\mathrm{H}$ showed the symmetrical deformation and antisymmetric deformation at $1386 \mathrm{~cm}^{-1}$ and $1454 \mathrm{~cm}^{-1}$, respectively. An overtone band of $980 \mathrm{~cm}^{-1}$ corresponding to alkene appeared at $1981 \mathrm{~cm}^{-1}$. A strong band at $1761 \mathrm{~cm}^{-1}$ is also recorded which belongs to carbonyl $(\mathrm{C}=\mathrm{O})$ group $[13,14]$. Since carbonyl group is directly attached to an electronegative atom, i.e. oxygen, that is why peak was appeared on higher field side. The spectrum exhibited a strong band at $1606 \mathrm{~cm}^{-1}$, this could be attributed to the stretching vibration of $\mathrm{C}=\mathrm{C}$ (aromatic ring). A number of bands for alkenes without plane stretching frequencies are shown in the range of $1000 \mathrm{~cm}^{-1}$ to $650 \mathrm{~cm}^{-1}$. The peaks appeared in the range of $1300 \mathrm{~cm}^{-1}$ to $1000 \mathrm{~cm}^{-1}$ corresponds to C-O-C $[15,16]$. It is reported that stretching frequency of Ag-O bond lies in the range of $253-205 \mathrm{~cm}^{-1}[17,18]$ which is out of limit of this IR spectrum. In this spectrum no $-\mathrm{OH}$ band could be seen which indicated the reaction progress and complex formation. In this study, all the observed vibrations are comparable with the literature.

\section{Powder X-ray diffraction analysis}

The complex was grinded and its X-ray powder diffraction analysis was done on X-ray powder diffractometer under $45 \mathrm{kV} / 40 \mathrm{~mA} \mathrm{X}$-ray, $2 \theta /^{\circ}$ scanning mode, fixed monocharomator and with a range from $2 \theta /{ }^{\circ}=10$ to 90 with a step of 0.02 degree for a period of $30 \mathrm{~min}$ as shown in Figure 3. Synthesized complex was analyzed through powder diffractometer for half an hour with a step of $0.03^{\circ}$ along fixed monochromator for $2 \theta$ value $\left(10^{\circ}-90^{\circ}\right)$. A total ten peaks were targeted and calculated their miller indices shown in Table 1.

In order to observe the novelty of synthesized silver complex, a comparison was made between the calculated pattern and reported patterns using peak search method. The measurement showed that peaks present at 10.2111, 10.4900, 12.0240, 22.4693, 25.3374, $27.1114,28.7865,37.0110,44.9786,64.4516\left(2 \theta /{ }^{\circ}\right)$ exhibit miller indices as $111,111,200,321$, $222,421,422,532,642,952$, respectively that confirm the uniqueness of the pattern. The material parameters like particle size, dislocation line density and strain of the synthesized product were also calculated as shown in Table 2.

Table 2 showed that the grain size was found to be in the range of $6.8005 \mathrm{~nm}$ at $2 \theta /^{\circ}=10.21$ to $4.0050 \mathrm{~nm}$ at $2 \theta /^{\circ}=64.45$. Less variation in dislocation density indicated the purity of the substance. 


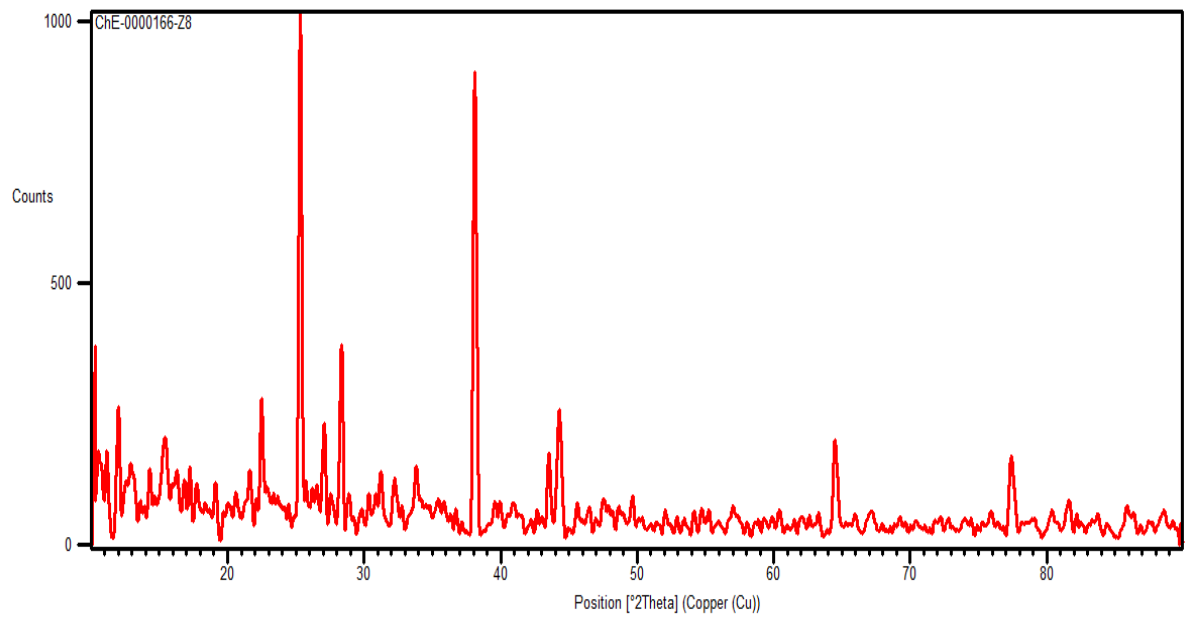

Figure 3. X-ray diffraction spectrum of silver complex with ethyl-5-hydroxy-2-oxo- $2 \mathrm{H}$ chromene-3-carboxylate.

Table 1. Claculation of miller indices through xrd diffraction pattern.

\begin{tabular}{|c|c|c|c|c|c|c|c|}
\hline $2 \theta /^{\circ}$ & $\theta /{ }^{\circ}$ & $\operatorname{Sin}^{2} \theta$ & $\begin{array}{l}1 \times \underline{\operatorname{Sin}^{2} \theta} \\
\operatorname{Sin}^{2} \theta_{\min }\end{array}$ & $\frac{2 \times}{\operatorname{Sin}^{2} \theta_{\min }}$ & $\frac{3 \times \frac{\operatorname{Sin}^{2} \theta}{\operatorname{Sin}^{2} \theta_{\min }}}{}$ & $\begin{array}{l}\text { Whole } \\
\text { integers }\end{array}$ & $H k l$ \\
\hline 10.2111 & 5.1055 & 0.00791 & 1 & 2 & 3 & 3 & 111 \\
\hline 10.4900 & 5.2450 & 0.00835 & 1.0556 & 2.1112 & 3.1668 & 3 & 111 \\
\hline 12.0240 & 6.0120 & 0.01096 & 1.3856 & 2.7712 & 4.1568 & 4 & 200 \\
\hline 22.4693 & 11.2346 & 0.03795 & 4.7977 & 9.5954 & 14.3931 & 14 & 321 \\
\hline 25.3374 & 12.6687 & 0.04809 & 6.0796 & 23.1722 & 12.1592 & 12 & 222 \\
\hline 27.1114 & 13.5557 & 0.05494 & 6.9456 & 13.8912 & 20.8368 & 21 & 421 \\
\hline 28.7865 & 14.3933 & 0.06179 & 7.8116 & 15.6232 & 23.4348 & 24 & 422 \\
\hline 37.0110 & 18.5055 & 0.10074 & 12.7357 & 25.4714 & 38.2073 & 38 & 532 \\
\hline 44.9786 & 22.4893 & 0.14631 & 18.4968 & 36.9936 & 55.4904 & 56 & 642 \\
\hline 64.4516 & 32.2258 & 0.28436 & 35.9494 & 71.8988 & 107.8482 & 108 & 952 \\
\hline
\end{tabular}

Table 2. Claculation of material parameters with the help of $2 \theta /^{\circ}$ value.

\begin{tabular}{|c|c|c|c|c|c|c|}
\hline $2 \theta /{ }^{\circ}$ & $\begin{array}{c}\text { FWHM } \\
{\left[{ }^{\circ} 2 \mathrm{Th} .\right]}\end{array}$ & $\begin{array}{c}\text { Intensity } \\
\text { counts }\end{array}$ & d-spacing $[\AA]$ & $\begin{array}{c}\text { Grain size }(\mathrm{D}) \\
(\mathrm{nm})\end{array}$ & $\begin{array}{c}\text { Dislocation } \\
\text { density }(\delta) \\
\left(\text { lines } / \mathrm{cm}^{-2}\right)\end{array}$ & $\begin{array}{c}\text { Strain }(\mathrm{S}) \\
(\text { lines }\end{array}$ \\
\hline 10.2111 & 0.2047 & 26.61 & 8.66309 & 6.8005 & 0.02162 & 0.0509 \\
\hline 10.4900 & 0.1535 & 17.25 & 8.43340 & 9.0742 & 0.01214 & 0.0382 \\
\hline 12.0240 & 0.2814 & 24.55 & 7.36069 & 4.9081 & 0.04151 & 0.0706 \\
\hline 22.4693 & 0.2303 & 23.12 & 3.95703 & 6.1405 & 0.02652 & 0.0564 \\
\hline 25.3374 & 0.2814 & 100.00 & 3.51523 & 5.0512 & 0.03919 & 0.0686 \\
\hline 27.1114 & 0.2814 & 18.37 & 3.28911 & 5.0696 & 0.03890 & 0.0683 \\
\hline 28.7865 & 0.2558 & 33.83 & 3.14528 & 5.5954 & 0.03194 & 0.0619 \\
\hline 37.0110 & 0.3582 & 89.50 & 2.36146 & 4.0828 & 0.05999 & 0.0849 \\
\hline 44.9786 & 0.3838 & 22.85 & 2.04406 & 3.9101 & 0.06540 & 0.0886 \\
\hline 64.4516 & 0.4093 & 17.44 & 1.44571 & 4.0050 & 0.06234 & 0.0865 \\
\hline
\end{tabular}




\section{Thermal gravimetric analysis}

Sample was analysed through TGA analyzer in inert atmosphere and decomposition pattern is given in Figure 4 . The major weight loss was observed in $1^{\text {st }}$ step with sharp decomposition in the range of $180{ }^{\circ} \mathrm{C}$ to $200{ }^{\circ} \mathrm{C}$. Further weight loss was observed in $2^{\text {nd }}$ step in the range of 250 ${ }^{\circ} \mathrm{C}$ to $590{ }^{\circ} \mathrm{C}$. In $1^{\text {st }}$ step one ligand out of two may be removed and in the $2^{\text {nd }}$ step the second ligand might be separated from the metal atom. The final residue in this analysis was undetermined.

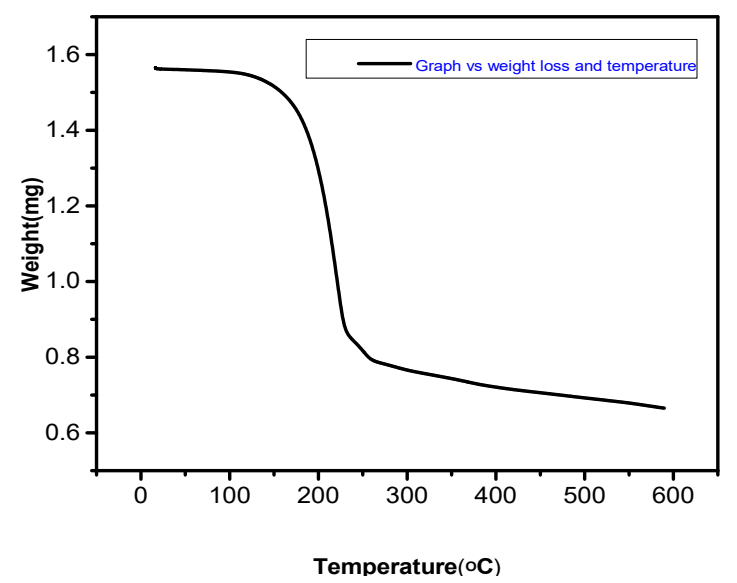

Figure 4. TGA curve of Ag metal with ethyl-5-hydroxy-2-oxo- $2 H$-chromene-3-carboxylate.

Electrospray ionization-mass spectrum (ESI-MS)

Mass spectra were done to check the composition and purity of the synthesized complex. Mass spectrometer for metal complexes with an ESI source is normally employed in an acidic media. In this analysis molecular ion peak is normally recorded as $[\mathrm{M}+\mathrm{H}]^{+}$ion cluster and due to the presence of sodium salt results a peak as $[\mathrm{M}+\mathrm{Na}]^{+}$. A molecular ion peak was recorded at $\mathrm{m} / \mathrm{z}$ 574.2334 which is associated to the $\left[\mathrm{C}_{24} \mathrm{H}_{18} \mathrm{AgO}_{10}+\mathrm{H}\right]^{+}$. A sharp peak was found at $\mathrm{m} / \mathrm{z}$ 596.0131 which was attributed to the ionic specie $\left[\mathrm{C}_{24} \mathrm{H}_{18} \mathrm{AgO}_{10}+\mathrm{Na}\right]^{+}$. Some extra peaks were also seemed in the spectra, which might be due to the presence of some impurities or due to the smaller fragments formed during decomposition.

Atomic absorption measurement

Atomic absorption analysis was done to find out metal to ligand ratio (by weight \%) in the synthesized complex. The sample and standard solutions were prepared according to standard procedure and following result was found.

Table 3. Concentration of silver metal complexes obtained experimentally.

\begin{tabular}{|l|l|l|}
\hline Sr. No. & Sample description & Amount of metal estimated by AAS (ppm) \\
\hline 1 & Sample (Z8) & 18.19 \\
\hline
\end{tabular}


Table 4. Expected metal to ligand ratio.

\begin{tabular}{|c|c|c|c|c|}
\hline S. No. & Ag metal & Ligand & Total weight & Metal (\%) \\
\hline 1 & 1 & 1 & 343.86 & 31.42 \\
\hline 2 & 1 & 2 & 579.92 & 18.51 \\
\hline 3 & 1 & 3 & 815.98 & 13.21 \\
\hline 4 & 1 & 4 & 1052.04 & 10.24 \\
\hline 5 & 1 & 5 & 1288.10 & 8.36 \\
\hline
\end{tabular}

To determine the exact formula of the complex, experimental result was compared with theoretical one. Atomic absorption analysis of the complex showed the metal concentration (weight \%) in the synthesized complex is $18.19 \%$ which is comparable with the theoretical data (18.51) of complex as shown in Table 4. The above results showed that metal/ligand ratio was $1: 2$. Thus the proposed formula of the complex was $\left[\mathrm{Ag}\left(\mathrm{C}_{12} \mathrm{H}_{9} \mathrm{O}_{5}\right)_{2}\right]$.

\section{Antibacterial activity of silver complexes}

Ligand and silver metal complex were screened to study their ability to inhibit the growth of a number of Gram-positive and Gram-negative bacterial strains. To study the effectiveness of ligand and metal complex three gram-positive strains i.e. S. aureus, B. subtilis and MRSA and three gram-negative strains i.e. E. coli, $S$. typhi and $P$. auruginosa were selected. It is reported that number of coumarin-based compounds show good antimicrobial activity [19-21]. Results of this study are shown in Table 5 .

Table 5. Antibacterial study of silver complex.

\begin{tabular}{|l|c|c|c|c|c|c|}
\hline \multirow{2}{*}{$\begin{array}{l}\text { Name of } \\
\text { compound }\end{array}$} & \multicolumn{6}{|c|}{ Diameter of inhibition zone (mm) } \\
\cline { 2 - 7 } & \multicolumn{3}{|c|}{ Gram positive } & Gram negative \\
\cline { 2 - 7 } & S. aureus & B. subtilis & MRSA & E. & P. auruginosa & S. typhi \\
\hline Ligand & 18 & - & - & 15 & - & 25 \\
\hline Ag-complex & 20 & 12 & - & 22 & 10 & 30 \\
\hline
\end{tabular}

Note: Mean inhibition zones are measured in $\mathrm{mm}$.

Ligand and Ag-complex did not show any activity against the growth of MRSA strain. The complex was found to be more effective against $S$. aureus, E. coli and $S$. typhi and reluctant their growth to a greater extent but ligand showed less activity against these strains. Another interesting result was observed in this study that ligand could not inhibit the growth of $P$. auruginosa and B. Subtilis but Ag-complex displayed moderate activity against both strains. Now it is clear from above discussion that activity of the ligand was considerably enhanced by introducing Ag metal atom.

The MIC values were the minimum concentration of the ligand and the complex required to inhibit $80 \%$ of the microbe's growth. The MIC values are given in Table 6 .

Table 6. MIC results of ligand and silver metal complex.

\begin{tabular}{|l|c|c|c|c|c|c|}
\hline \multirow{2}{*}{$\begin{array}{l}\text { Name of } \\
\text { compound }\end{array}$} & \multicolumn{3}{|c|}{ MIC values against various pathogens $(\mu \mathrm{g})$} \\
\cline { 2 - 7 } & \multicolumn{3}{|c|}{ Gram positive } & E. coli & P. auruginosa & S. typhi \\
\cline { 2 - 7 } & S. aureus & B. Subtilis & MRSA & $15 \mu \mathrm{g}$ & - & $15 \mu \mathrm{g}$ \\
\hline Ligand & $20 \mu \mathrm{g}$ & - & - & $10 \mu \mathrm{g}$ & $25 \mu \mathrm{g}$ & $10 \mu \mathrm{g}$ \\
\hline Ag-complex & $15 \mu \mathrm{g}$ & $30 \mu \mathrm{g}$ & - & \multicolumn{3}{c|}{ Gram negative } \\
\hline
\end{tabular}


The MIC value of ligand and Ag-complex for S. aureus, E. coli and S. typhi were $20 \mu \mathrm{g}, 15$ $\mu \mathrm{g}, 15 \mu \mathrm{g}$ and $15 \mu \mathrm{g}, 10 \mu \mathrm{g}, 10 \mu \mathrm{g}$, respectively. Similarly for B. subtilis and P. auruginosa, ligand proved inactive but Ag-complex inhibited their growth and showed MIC values of $30 \mu \mathrm{g}$ and $25 \mu \mathrm{g}$, respectively. Ag-complex showed lower MIC values than ligand and it is a big clue of enhanced antibacterial activity of the silver complex against pathogens.

\section{CONCLUSION}

A new complex $\left[\mathrm{Ag}\left(\mathrm{C}_{12} \mathrm{H}_{9} \mathrm{O}_{5}\right)_{2}\right]$ with coumarin based ligand was synthesized. Structural studies were done by using atomic absorption spectroscopy, TGA and X-ray measurements. The material parameters of complex including grain size, dislocation density, and stress have been calculated. Antibacterial study proved the enhancement in activity of ligand by introducing silver metal against various pathogens.

\section{ACKNOWLEDGEMENTS}

The authors are very grateful to Chairman, Chemistry Department UET, Lahore for her persistent creative encouragement and valuable guidance throughout the research work. We also acknowledge Higher Education Commission (HEC) of Pakistan for providing financial support.

\section{REFERENCES}

1. Weber, U.S.; Steffen, B.; Siegers, C.P. Antitumor-activities of coumarin, 7-hydroxycoumarin and its glucuronide in several human tumor cell lines. Res. Commun. Mol. Pathol. Pharmacol. 1998, 99, 193-206.

2. Patil, A.D.; Freyer, A.J.; Drake, S.E.; Haltiwanger, R.C.; Bean, M.F.; Taylor, P.B.; Caranfa, M.J.; Breen, A.L.; Bartus, H.R. The inophyllums, novel inhibitors of HIV-1 reverse transcriptase isolated from the Malaysian tree, Calophyllum inophyllum Linn. J. Med. Chem. 1993, 36, 4131-4138.

3. Yun, B.S.; Lee, I.K.; Ryoo, I.J.; Yoo, I.D. Coumarins with monoamine oxidase inhibitory activity and antioxidative coumarino-lignans from Hibiscus syriacus. J. Nat. Prod. 2001, 64, 1238-1240.

4. Zaha, A.A.; Hazem, A. Antimicrobial activity of two novel coumarin derivatives: 3cyanonaphtho $\{1,2-(\mathrm{e})\}$ pyran-2-one and 3-cyanocoumarin. New Microbiol. 2002, 25, 213 222.

5. Maly, D.J.; Leonetti, F.; Backes, B.J.; Dauber, D.S.; Harris, J.L.; Craik, C.S.; Ellman, J.A. Expedient solid-phase synthesis of fluorogenic protease substrates using the 7-amino-4carbamoylmethylcoumarin (ACC) fluorophore. J. Org. Chem. 2002, 67, 910-915.

6. Clarke, M.J. Ruthenium metallopharmaceuticals. Coord. Chem. Rev. 2002, 236, 297-299.

7. Bassetti, S.; Hu, J.; D'Agostino, R.B.; Sherertz, R.J. Prolonged antimicrobial activity of a catheter containing chlorhexidine-silver sulfadiazine extends protection against catheter infections in vivo. Antimicrob. Agents Chemother. 2001 , 45, 1535-1538.

8. Djokić, S. Treatment of various surfaces with silver and its compounds for topical wound dressings, catheter and other biomedical applications. ECS Transactions 2008, 11, 1-12.

9. Stillman, M.J.; Presta, A.; Gui, Z.; Jiang, D.T. Spectroscopic studies of copper, silver and gold metallothioneins. Metal-Based Drugs 1994, 1, 375-394.

10. Sugino, T.; Tanaka, K. Solvent-free coumarin synthesis. Chem. Lett. 2001, 30, 110-111. 
11. Azócar. M.I.; Muñoz, H.; Levin, P.; Dinamarca, N.; Gómez, G.; Ibañez, A.; Garland, M.T.; Paez, M.A. Synthesis and characterization of silver(I) complexes with ligands having anti-inflammatory properties. Commun. Inorg. Synth. 2013, 1, 19-21.

12. Bunce, S.J.; Edwards, H.G.; Johnson, A.F.; Lewise, I.R.; Turner, P.H. Polycyclic aromatic compounds. Spectrochim. Acta A 1993, 49, 773-785.

13. Smith, B. Infrared Spectral Interpretaion, A Systematic Approach, CRC Press: Washington; USA; 1999.

14. Peesole, R.L.; Shield, L.D.; McWillam, I.C. Modern Methods of Chemical Analysis, Wiley: New York; USA; 1976.

15. Pavia, D.L.; Lampman, G.M.; Kriz, G.S.; Vyvyan J.R. Introduction to Spectroscopy, 4th ed., Brooks/Cole: USA; 2008; p 752.

16. Halli, M.B.; Vithal Reddy, P.; Sumathi, R.B.; Basavaraja, A. Synthesis, spectral characterization and antimicrobial studies of metal(II) complexes with (12E)-N'-[1-(2-oxo2H-chromen-3-yl)ethylidene]benzofuran carbohydrazide. Der Pharma Chemica 2012, 4, $1214-1225$.

17. Morzyk-Ociepa, B.; Michalska, D. FT-Raman and infrared spectra of silver(I) complexes with glutarimidate and 3,3-dimethylglutarimidate anions. Spectrochem. Acta A: Mol. Biomol. Spectros. 1999, 55, 2671-2676.

18. Creaven, B.S.; Egan, D.A.; Kavanagh, K.; McCann, M.; Noble, A.; Thati, B.; Walsh, M. Synthesis, characterization and antimicrobial activity of a series of substituted coumarin-3carboxylatosilver(I) complexes. Inorg. Chim. Acta 2006, 359, 3976-984.

19. Borges, F.; Roleira, F.; Milhazes, N.; Santana, L.; Uriate, E. Simple coumarins and analogues in medicinal chemistry: occurrence, synthesis and biological activity. Curr. Med. Chem. 2005, 12, 887-916.

20. Khan, I.A.; Kulkarni, M.V.; Gopal, M.; Shahabuddin, M.S.; Sun, C.-M. Synthesis and biological evaluation of novel angularly fused polycyclic coumarins. Bioorg. Med. Chem. Lett. 2005, 15, 3584-3587.

21. Devienne, K.F.; Raddi, G.; Coelho, R.G.; Vilegas, W. Structure and antimicrobial activity of some natural isocoumarins and their analogues. Phytomedicine 2005, 12, 378-381. 